Review articles Studia luridica Lublinensia vol. XXX, 2, 2021 DOI: 10.17951/sil.2021.30.2.447-457

Tomasz Tulejski

University of Lodz, Poland

ORCID: 0000-0001-9466-1173

ttulejski@wpia.uni.lodz.pl

\title{
Prawo rzymskie to nie tylko Digesta. Kilka uwag nad książką Łukasza Jana Korporowicza "Prawo rzymskie w Anglii w XVIII wieku. Nauczanie, studia, nauka"
}

\author{
Roman Law is not only Digesta: \\ A Few Remarks on Łukasz Jan Korporowicz's Book \\ "Prawo rzymskie w Anglii w XVIII wieku. Nauczanie, studia, nauka"
}

\section{ABSTRAKT}

Polskie badania nad prawem rzymskim tradycyjnie dotyczą przede wszystkim prawa prywatnego oraz jego recepcji w europejskich systemach prawnych. Niewiele publikacji dotyczy jednak roli, jaką prawo rzymskie odegrało na Wyspach Brytyjskich. Jednym z istotnych wyjątków są badania Łukasza Jana Korporowicza z Uniwersytetu Łódzkiego. W niniejszym artykule przeprowadzono analizę jego ostatniej książki pt. Prawo rzymskie w Anglii w XVIII wieku. Nauczanie, studia, nauka. Opisuje ona system nauczania prawa rzymskiego w Anglii w XVIII w. oraz rolę, jaką absolwenci studiów romanistycznych w Oxbridge odgrywali w ówczesnym społeczeństwie angielskim. Wskazano przede wszystkim na pionierski charakter recenzowanej pracy, podobna bowiem nie ukazała się jeszcze nie tylko w Polsce, ale i na świecie. Analizując kolejne części książki, dokonano ich krytycznej analizy oraz wskazano na jej silne i słabsze elementy. W konkluzjach wskazano na bardzo wysoki poziom naukowy recenzowanej książki.

Słowa kluczowe: prawo rzymskie; system nauczania; studia romanistyczne; społeczeństwo angielskie

CORRESPONDENCE ADDRESS: Tomasz Tulejski, PhD, dr. habil., Full Professor, University of Lodz, Faculty of Law and Administration, Kopcinskiego 8/12, 90-232 Lodz, Poland. 
Badania nad prawem rzymskim mają w naszym kraju bogatą przeszłość i nie mniej istotne osiągnięcia. Kilka pokoleń polskich romanistów wniosło bowiem istotny wkład w światowe badania nad dziedzictwem prawnym starożytnego Rzy$\mathrm{mu}$, jego substancjalnym zdekodowaniem oraz recepcją w europejskich porządkach prawnych. Badania te koncentrowały się przede wszystkim na rzymskim prawie prywatnym, choć - co zauważam $\mathrm{z}$ dużą satysfakcją - w ostatnich latach widać także rosnące zainteresowanie wśród polskich badaczy prawem publicznym i ustrojowym. ${ }^{1} \mathrm{Na}$ tym tle od lat wyróżnia się aktywność naukowa Łukasza Jana Korporowicza, przedstawiciela łódzkiej szkoły romanistycznej, stworzonej przed laty przez Borysa Łapickiego, którego dziedzictwo rozwijane było i kontynuowane przez Cezarego Kunderewicza, Jana Kodrębskiego i Annę Pikulską-Radomską. Oryginalność badań Ł.J. Korporowicza sprowadza się do analizy recepcji prawa rzymskiego na Wyspach Brytyjskich, a zatem tam, gdzie zgodnie obiegową opinią była ona najsłabsza, a nawet $\mathrm{z}$ różnych przyczyn programowo została odrzucona. Efektem jego angielskich zainteresowań jest opublikowana w 2016 r. doskonała monografia pt. Prawo rzymskie w orzecznictwie Izby Lordów w latach 1876-2009. ${ }^{2}$ Autor wykazał w niej ponad wszelką wątpliwość ogromny wpływ, jaki prawo rzymskie wywarło na angielską judykaturę oraz kształt common law. Zadał w niej zarazem kłam często pokutującemu po obu stronach Kanału La Manche przekonaniu o nieprzenikalności common law i civil law, skutecznie bowiem wykazał niemal stałą obecność prawa rzymskiego w orzecznictwie Izby Lordów, pokazując liczne romanistyczne inspiracje, a nawet argumentacje stosowane przez lordów prawa. Nie rozwodząc się nad wieloma zaletami tej pracy, wskazać należy jej jedyną moim zdaniem niedoskonałość. Otóż Autor nie wskazał w sposób wystarczający źródeł wiedzy sędziów z zakresu prawa rzymskiego - po lekturze monografii nie wiemy, skąd ją czerpali ani jakie było źródło ich romanistycznej inspiracji.

Piszę o tym nie bez kozery, ponieważ w mojej opinii kwestie te wyjaśnia najnowsza książka Ł.J. Korporowicza, która jest swoistą kontynuacją podjętych w poprzedniej monografii analiz oraz wyjaśnia kwestie, które wydały się dla mnie zbyt mało pogłębione i zaakcentowane. W 2019 r. nakładem Wydawnictwa Uniwersytetu Łódzkiego ukazała się monografia pt. Prawo rzymskie w Anglii w XVIII wieku. Nauczanie, studia, nauka, ${ }^{3}$ której poświęcę kilka uwag. Na początku wypada wyjaśnić, dlaczego ktoś, kto zajmuje się filozofią polityczną, a nie prawem rzymskim sensu stricto, ośmiela się zabrać głos i oceniać dorobek znajdujący się

\footnotetext{
1 A. Jurewicz, R. Sajkowski, B. Sitek, J. Szczerbowski, A. Świętoń, Rzymskie prawo publiczne. Wybrane zagadnienia, Olsztyn 2011; P. Krajewski, B. Sitek, Rzymskie prawo publiczne, Olsztyn 2006; A. Dębiński, J. Misztal-Konecka, M. Wójcik, Prawo rzymskie publiczne, Warszawa 2017; A. Tarwacka, J. Zabłocki, Publiczne prawo rzymskie, Warszawa 2011.

2 Ł.J. Korporowicz, Prawo rzymskie w orzecznictwie Izby Lordów w latach 1876-2009, Łódź 2016.

Idem, Prawo rzymskie w Anglii w XVIII wieku. Nauczanie, studia, nauka, Łódź 2019.
} 
niejako poza jego głównym nurtem zainteresowań. Tak się jednak składa, że zajmując się od ponad dwóch dekad klasyczną angielską/brytyjską myślą polityczną i ustrojową, nie mogłem nie zauważyć, jak ważnym punktem odniesienia jest dla niej szeroko pojęta rzymska tradycja zarówno prawna, jak i polityczna, których moim zdaniem nie wolno rozdzielać. Mówiąc inaczej, dla pełnego zrozumienia historii prawa angielskiego oraz angielskiej myśli politycznej niepodobna zlekceważyć rzymskiego wątku, który się w niej przewija co najmniej od czasów Vacariusa, który przybył do Anglii około 1143 r. i stworzył pierwszą szkołę prawa rzymskiego, wyprzedzającą te, które powstały we Francji i w Świętym Cesarstwie Rzymskim. Wątek ten przewija się nieustannie i widać go w pierwszych pomnikach angielskiego prawa, w Glanvill ${ }^{4}$ i Bracton. ${ }^{5}$ Również wybitni angielscy historycy prawa i ustroju dostrzegają ową zależność i infiltrację romanizmu na Wyspach. Wystarczy tu wspomnieć choćby Charlesa H. McIlwaina, ${ }^{6}$ Fredericka Pollocka i Frederica W. Maitlanda, ${ }^{7}$ a ze współczesnych Petera Steina, ${ }^{8}$ Richarda H. Helmholza ${ }^{9}$ czy Davida Ibbetsona. ${ }^{10}$ Zachowując proporcje, Ł.J. Korporowicz wpisuje się zatem w długą i szacowną tradycję intelektualną, która stara się wykazać, że w tym zakresie Kanał La Manche nie jest nieprzekraczalnym limes, a europejską tradycję prawną da się traktować jako jedność, której Anglia jest jednym z konarów, pozostając jednak w łączności z jej pniem głównym wyrosłym na rzymskim podglebiu. Podobnie jak poprzednia monografia Autora, także i ta - choć argumentując z innego punktu wyjścia - zrywa z obiegową opinią o fundamentalnej awersji Anglików, wynikającej z przyczyn polityczno-religijnych, do prawa rzymskiego i jego całkowitej marginalizacji na Wyspach. Fałszywość tej tezy oczywista jest dla tych, którzy na polu naukowym mieli do czynienia z prawem angielskim, lecz w nauce polskiej brak było do tej pory pracy, w której podjęto by tę kwestię w sposób tak kompleksowy i wielowątkowy. O ile w pierwszej monografii Korporowicz wskazał na, rzekłbym, materialne elementy prawa rzymskiego, o tyle tutaj skupia

4 H.J. Berman, Prawo i rewolucja. Ksztattowanie się zachodniej tradycji prawnej, Warszawa 1995, s. 527; R.V. Turner, Roman Law in England before the Time of Bracton, "Journal of British Studies" 1975, vol. 15(1), s. 1-25.

5 P. Vinogradoff, The Roman Elements in Bracton's Treatise, "The Yale Law Journal" 1923, vol. 32(8), s. 751-756; H.G. Richardson, Azo, Drogheda, and Bracton, "The English Historical Review" 1944, vol. 59(233), s. 22-47; idem, Tancred, Raymond, and Bracton, "The English Historical Review" 1944, vol. 59(235), s. 376-384.

6 Ch.H. McIlwain, Constitutionalism: Ancient and Modern, Ithaca 1947.

7 F. Pollock, F.W. Maitland, The History of English Law before the Time of Edward I, Cambridge 1898.

8 P. Stein, The Character and Influence of the Roman Civil Law: Historical Essays, London 1988; idem, Roman Law in European History, New York 1999.

9 R.H. Helmholz, Canon Law and English Common Law, London 1983; idem, Roman Canon Law in Reformation England, Cambridge - New York 1990.

10 D. Ibbetson, Common Law and Ius Commune, London 2001. 
się na wskazaniu roli romanistycznego wykształcenia i romanistycznej formacji na kreację angielskich elit.

Punktem wyjścia rozważań w recenzowanej monografii jest analiza instytucjonalna sądownictwa angielskiego z jego wyraźnym rozróżnieniem materialnym i proceduralnym na sądy królewskie, admiralicji i kościelne. Pierwsze operowały w ramach common law, podczas gdy dwa pozostałe posługiwały się procedurą rzymsko-kanoniczną. $Z$ tego faktu wynikała oczywista potrzeba istnienia wykwalifikowanej kadry prawników posiadających wiedzę na temat prawa rzymskiego i kanonicznego. Ośrodkami, w których mogli ją zdobyć, były uniwersytety w Oxfordzie i Cambridge. Niepokoje społeczne wywołane Aktem Supremacji, porzuceniem Rzymu, a w kolejnym stuleciu sporami pomiędzy Koroną i Parlamentem wpłynęły jednak na znaczące pogorszenie jakości kształcenia. W tych okolicznościach Ł.J. Korporowicz stawia fundamentalne pytanie o kondycję nauki i nauczania prawa rzymskiego w XVIII w. w Anglii. Aby udzielić na nie odpowiedzi, bada trzy komplementarne wobec siebie aspekty wyspiarskiej romanistyki: nauczanie prawa rzymskiego, kształt studiów prawniczych oraz nauki prawa rzymskiego. Odpowiedź na to pytanie jest ważna z uwagi na kryzys, jaki dotknął w owym czasie angielskie uniwersytety. Był on elementem fundamentalnego kryzysu politycznego charakteryzującego angielski XVII wiek. Spór pomiędzy Stuartami a Parlamentem, głębokie podziały religijne w społeczeństwie angielskim oraz bardzo dynamiczna sytuacja międzynarodowa nie pozostały bez wpływu na kondycję angielskich uniwersytetów w wieku następnym. George M. Trevelyan, pisząc o tym, skonstatował, że

śpiączka uniwersytetów angielskich w XVIII stuleciu była bardziej skandaliczna niż lżejsza i częściej przerywana drzemka kościoła. Praktycznie biorąc, nie odbywały się żadne egzaminy w Oxfordzie, a nieliczne w Cambridge, a w porównaniu z czasami pierwszych Stuartów liczba studentów skurczyła się prawie o połowę. ${ }^{11}$

Ten ogólny marazm i degeneracja nie dotknął, co interesujące, w tym samym zakresie nauczania ius romanum, dlatego studia z prawa rzymskiego na tle innych studiów wydają się być wyjątkiem od opisanej przez Trevelyana reguły. Tym bardziej uzasadniony jest też trud badawczy podjęty przez Ł.J. Korporowicza, zwłaszcza że - co może dziwić - nawet w nauce anglosaskiej nie ma kompleksowego studium poświęconego tej tematyce. O nauczaniu prawa rzymskiego na Wyspach w XVII ${ }^{12}$ i XIX ${ }^{13}$ w. znaleźć możemy w literaturze szereg informacji, ale na temat rozdzielającego je stulecia nauka angielska niestety (i na szczęście dla Autora) w zasadzie milczy. Dlaczego tak jest, trudno w istocie orzec, choć pewną

${ }^{11}$ G.M. Trevelyan, Historia Anglii, Warszawa 1967, s. 623-624.

12 B.P. Levack, The Civil Lawyers in England, 1603-1641: A Political Study, Oxford 1973.

${ }_{13}$ M.H. Hoeflich, Roman and Civil Law and the Development of Anglo-American Jurisprudence in the Nineteenth Century, Athens 1997. 
wskazówką może być ogólna tendencja angielskich historyków i historyków prawa, by zajmować się okresami politycznych i prawnych przesileń, a wiek XVIII do czasu rewolucji francuskiej w takie nie obfituje.

Wracając do recenzowanej monografii, w pierwszym rozdziale Ł.J. Korporowicz analizuje zagadnienia związane ze statusem prawnym profesorów prawa rzymskiego, charakterem prowadzonych przez nich wykładów oraz ich zaangażowaniem w życie uczelni i życie polityczno-prawne Anglii. Mimo że za sprawą Henryka VIII doszło do zerwania z Rzymem oraz wprowadzenia zakazu nauki prawa kanonicznego, to z przyczyn praktycznych (sądownictwa kościelnego) pozostawiono wydziały prawa rzymskiego w Oxford i Cambridge. Nie sposób w tym miejscu nie docenić drobiazgowości wywodów Autora, gdy opisuje kwestie personalne oraz zaangażowanie profesorów $\mathrm{np}$. w debaty parlamentarne. Wielkie wrażenie musi robić to, jak szkicuje on kolejne sylwetki profesorów prawa rzymskiego, wskazuje na ich kompetencje (lub ich brak) i naukowe osiągnięcia, analizuje podręczniki, komentarze i traktaty. Z tego opisu wyłania się barwny obraz intelektualnego życia angielskich cywilistów katedr królewskich oraz dynamika badań nad prawem rzymskim. Został on sporządzony w oparciu nie tylko o piśmiennictwo naukowe, lecz także solidne badania archiwalne przeprowadzone w Oxford i Cambridge. Szczególnie zainteresowało mnie zauważenie faktu, że angielscy cywiliści, podobnie jak prawnicy common law, swoje zainteresowania kierowali zarówno w kierunku prawa prywatnego, jak i prawa publicznego oraz ius gentium, obficie korzystając przy tym z dorobku kontynentalnej szkoły prawa natury. Po raz kolejny dowodzi to faktu infiltracji Wysp przez kontynentalną filozofię prawa oraz potrzebę znajomości przez angielskich prawników choćby fundamentów prawa rzymskiego, niezbędnego również dla celów polemicznych. Jeśli bowiem weźmiemy pod uwagę najważniejsze międzynarodowe polemiki XVII i XVIII w. (zwłaszcza dotyczące prawa międzynarodowego), to stwierdzimy, że tym co łączy prawników z obu stron Kanału, jedynym wspólnym językiem, w którym mogą argumentować, cały czas pozostaje prawo rzymskie. Oczywiście wiedza na jego temat nie była zdobywana tylko w ramach katedr królewskich, dlatego Ł.J. Korporowicz dużą część analizy poświęca nauczaniu ius romanum poza ich strukturą. Prawo rzymskie wykładane było bowiem przez członków kolegiów uniwersyteckich, którzy również byli cywilistami, w Inns of Courts oraz szkołach prywatnych. Tym kwestiom Autor przygląda się też szczegółowo, analizując programy studiów i biografie naukowe wykładowców oraz poddając romanistycznej ocenie treść ich rozpraw naukowych. Możemy dowiedzieć się na przykład, że prawo rzymskie było przedmiotem zainteresowania prawników commom law, a dla zostania barristerem konieczne było odbycie studiów z zakresu prawa rzymskiego. ${ }^{14}$ Ciekawy szczegół, na który zwróciłem uwagę ze względu na moje zainteresowania naukowe, dotyczy Jamesa

${ }^{14}$ Ł.J. Korporowicz, Prawo rzymskie w Anglii..., s. 66. 
MacIntosha, który prowadził w 1799 r. wykład w Lincoln’s Inn dotyczący prawa narodów i nie zabrakło w nim licznych odwołań do prawa rzymskiego. ${ }^{15} \mathrm{~W}$ pracy Ł.J. Korporowicza roi się zresztą od tego typu ciekawostek i „smaczków”, co sprawia, że lektura jego monografii nie jest nużąca, a przeciwnie - potrafi wielokrotnie rozbudzić intelektualne pasje. Szczegółowość jego rozważań jest czasami zaskakująca, jak np. wtedy gdy skrupulatnie referuje, ile i jakich dzieł z zakresu prawa rzymskiego nabyły korporacje prawnicze. ${ }^{16}$

To spojrzenie na nauczanie prawa rzymskiego z perspektywy wykładowców uzupełnione jest o rozważania dotyczące drugiej strony procesu dydaktycznego, dlatego możemy poznać etapy zdobywania stopni bakałarza i doktora prawa rzymskiego na uniwersytetach w Oxford i Cambridge. I tutaj szczegółowość narracji musi budzić uznanie, ponieważ obok drobiazgowego przedstawienia poszczególnych stopni kariery akademickiej można się wiele dowiedzieć o szczegółach uroczystości związanych z ich otrzymaniem. Autor nie miał przy tym łatwego zadania ze względu na częste zmiany regulacji dotyczących tej kwestii oraz prawdziwy gąszcz różnych konkurencyjnych procedur. Przy okazji poznajemy wiele szczegółów na temat samego studiowania w XVIII stuleciu w Oxbridge. Autor do swych rozważań załączył bowiem szczegółowe tabele dotyczące liczby studentów w poszczególnych kolegiach i hallach obu uniwersytetów. Zwieńczeniem tej części pracy jest omówienie pozaakademickich sposobów otrzymania stopnia doktora prawa rzymskiego. Takowy otrzymał m.in. Tadeusz Burzyński, marszałek Trybunału Głównego Wielkiego Księstwa Litewskiego, a później poseł nadzwyczajny Rzeczypospolitej w Królestwie Wielkiej Brytanii w latach $1769-1773,{ }^{17}$ a także Benjamin Franklin i Peter Oliver.

$\mathrm{Z}$ uwagi na moje naukowe zainteresowania szczególną uwagę przykuła kolejna część monografii, która traktuje o roli cywilistów w życiu społeczno-politycznym XVIII-wiecznej Anglii. Jak zauważa Ł.J. Korporowicz, ,jedynie niewielka część wszystkich studentów prawa rzymskiego mogła poświęcić się praktyce sądowej. Dla wielu studiowanie civil law było jednak początkiem drogi, która w przyszłości miała doprowadzić ich na pozycje liderów angielskiego życia i społeczeństwa". ${ }^{18}$ Okazuje się, że studia romanistyczne uważano wówczas za część dobrze widzianej społecznej formacji intelektualnej prawników common law, polityków czy innych liderów społeczeństwa. $Z$ oczywistych względów większość angielskich cywilistów zajmowała się praktyką w sądach kościelnych i Admiralicji, lecz - jak pokazuje Autor monografii - takie uogólnienie byłoby bardzo krzywdzące. Wielu absolwen-

15 Ibidem, s. 68-70.

16 Ibidem, s. 71.

17 Rocznik Stużby Zagranicznej Rzeczypospolitej Polskiej wedtug stanu na 1 kwietnia 1938, Warszawa 1938, s. 146.

18 Ł.J. Korporowicz, Prawo rzymskie w Anglii..., s. 121. 
tów studiów romanistycznych pełniło w XVIII w. posługę biskupów anglikańskich, kwerenda Ł.J. Korporowicza wykazała, że było ich aż 24. Inni pełnili wysokie funkcje kościelne, wielu było dziekanami kapituł katedralnych czy kanclerzami sądów konsystorskich. Ponadto absolwenci Oxbridge angażowali się w działalność korporacji prawniczych common law. Warto dodać, że wielu prawników common law uzyskało stopień bakałarza czy doktora prawa rzymskiego. Georg Clarke, absolwent All Souls College, został sekretarzem wojny, a później jednym z Lordów Admiralicji, podobnie jak George Lee oraz Georg Hey, jeden z najwybitniejszych ówczesnych cywilistów. ${ }^{19}$ Charles Talbot, późniejszy baron Talbot of Hensol, absolwent Oxfordu, pełnił funkcję Lorda Kanclerza Wielkiej Brytanii. Najsłynniejszym XVIII-wiecznym cywilistą był jednak William Blackstone, uważany również za jednego z największych w historii prawników common law. Był on Sędzią Sądu Ławy Królewskiej oraz Sądu Spraw Pospolitych. W tym miejscu muszę niestety przyznać, że oczekiwałem od Autora rozwinięcia tego wątku. Miałem nadzieję, że dowiem się o rzymskich inspiracjach Blackstone'a oraz o wpływie, jaki wywarły studia w Oxfordzie na jego Commentaries of the Laws of England. Już we wstępie do nich stwierdza bowiem, że prawo rzymskie „nie było całkowicie zaniedbane w narodzie angielskim i nie jest jego zamiarem, by odstąpić od studiowania prawa cywilnego, uważanego [...] za zbiór zapisanego rozumu". ${ }^{20}$ Mimo że zaznacza zaraz, iż „nie możemy poświęcać naszej czci wobec Alfreda i Edwarda na rzecz Teodozjusza i Justyniana; nie możemy preferować edyktu pretora, albo reskryptu cesarskiego nad nasze odwieczne zwyczaje albo sankcję naszego angielskiego parlamentu", ${ }^{21}$ to wpływ jego romanistycznej formacji jest niebywale widoczny w terminologii oraz konstrukcji jego wielkiego dzieła. ${ }^{22}$ Takich rozważań oczekuje, jak śmiem twierdzić, polski czytelnik, a chyba nikt tak bardzo, jak Ł.J. Korporowicz, nie jest tak kompetentny, by się nimi zająć. Wracając do tematu, Autor przytacza także liczne przykłady cywilistów pozostających w służbie dyplomatycznej Korony, w tym najsłynniejszego Davida Murraya, drugiego hrabiego Mansfield, ministra w gabinecie Lorda Northa i Lorda Przewodniczącego Tajnej Rady. Nie był on zresztą jedynym cywilistą, który zrobił karierę polityczną. Jak dowiadujemy się z recenzowanej monografii, w XVIII w. aż 76 posłów do Izby Gmin posiadało stopnie akademickie z zakresu prawa rzymskiego. Bez wątpienia najważniejszym z nich był Robert Walpole - uważany za pierwszego premiera Zjednoczonego Królestwa - który uzyskał doktorat z prawa rzymskiego w Cambridge. Pokazuje

19 Ibidem, s. 145 .

${ }^{20}$ W. Blackstone, Commentaries on the Laws of England, Philadelphia 1893, s. 4.

${ }^{21}$ Ibidem, s. 5.

22 A. Watson, The Structure of Blackstone's Commentaries, "Yale Law Journal” 1988, vol. 97(5), s. 759-821; D. Kennedy, The Structure of Blackstone's Commentaries, "Buffalo Law Review" 1979, vol. 2(28), s. 227, 247; M. Minot, The Irrelevance of Blackstone: Rethinking the Eighteenth-Century Importance of the Commentaries, "Virginia Law Review" 2018, vol. 104(7), s. 1363, 1369-1372. 
to, wbrew funkcjonującej w literaturze opinii, że cywiliści nie byli związani jedynie z sądami kościelnymi i admiralicji. Choć rzeczywiście wielu koncentrowało się na różnych aspektach działalności Kościoła państwowego, to wielu - o czym była mowa wyżej - angażowało się w politykę, dyplomację, a nawet w praktykę common law. Można, a nawet trzeba zatem przyjąć, że absolwenci prawa rzymskiego byli niedającym się zignorować, ważnym elementem angielskiej elity intelektualnej XVIII w.

Ostatnia część monografii poświęcona została XVIII-wiecznej literaturze romanistycznej i badaniach nad prawem rzymskim. Analizując to zagadnienie w sposób jak zawsze drobiazgowy i wyczerpujący, Ł.J. Korporowicz poddaje ocenie publikacje źródeł prawa rzymskiego, prace systematyczne oraz opracowania monograficzne. Uwagę zwraca też obszerna, niemalże kompletna literatura przedmiotu, jaką posługuje się Autor, w swym zasadniczym zrębie prawie całkowicie anglojęzyczna.

Oceniając wartość merytoryczną monografii Prawo rzymskie w Anglii w XVIII wieku. Nauczanie, studia, nauka, raz jeszcze należy podkreślić jej absolutnie pionierski charakter. W nauce polskiej o angielskich cywilistach traktują jedynie bardzo interesujące prace Łukasza Marca $^{23}$ z Uniwersytetu Jagiellońskiego, ale dotyczą one w zasadzie XVI i XVII w. Podobna sytuacja, co zastanawiające, panuje w nauce anglosaskiej, która do tej pory nie doczekała się monografii dotyczącej prawa rzymskiego w XVIII-wiecznej Anglii. Jako badacz angielskiej teorii i filozofii państwa i prawa tego okresu składam to, jak wskazałem wcześniej, na karb wyrazistego kontekstu politycznego, jaki miał miejsce w dwóch wiekach poprzedzających badany przez Ł.J. Korporowicza okres. Tymczasem skupił się on na okresie takich fundamentalnych kontrowersji pozbawionym, co jednak pozwoliło na rzeczowe i wolne od politycznego napięcia przeanalizowanie rzeczywistej roli, jaką prawo rzymskie odgrywało w intelektualnym obrazie Albionu. Dlatego uważam za potrzebne, a nawet konieczne przełożenie recenzowanej monografii na język angielski! Odnosząc się do warsztatu naukowego Autora, należy uznać, że znajduje się on na bardzo wysokim poziomie. Nie tylko doskonale analizuje literaturę przedmiotu, lecz także - co bardzo ważne - dokonuje własnych ustaleń na podstawie badań archiwalnych. Dzięki temu buduje argumenty pozwalające poddać trafnej i rzeczowej krytyce wiele $\mathrm{z}$ dotychczasowych ustaleń doktryny.

Recenzowana monografia nie jest dziełem stawiającym jedynie pytania i zachęcającym do dalszych badań, lecz stojącą na bardzo wysokim poziomie analizą skomplikowanego i wielowymiarowego zagadnienia. Autor w sposób swobodny i znamionujący ogromną wiedzę porusza się w analizowanych zagadnieniach, jego

${ }^{23}$ Zob. np. Ł. Marzec, Civil lawyers w Anglii Tudorów i wczesnych Stuartów, „Czasopismo Prawno-Historyczne” 2003, vol. 55(2); idem, Kilka uwag o sadownictwie Admiralicji w Anglii, ,Zeszyty Prawnicze UKSW" 2004, vol. 1(1); idem, Prawo rzymskie w dawnej Anglii w świetle pogladów Artura Ducka, „Zeszyty Prawnicze UKSW” 2006, vol. 6(2). 
wywód jest spójny i logiczny, a argumenty przytaczane dla uzasadnienia stawianych tez są przekonujące. Monografia napisana jest bardzo ładnym i przejrzystym językiem, imponuje łatwość, z jaką Autor porusza się po trudnych zagadnieniach, a także dojrzałość $\mathrm{w}$ formułowaniu i udowadnianiu tez. Mimo drobiazgowości wywodu Ł.J. Korporowicz nie utknął w nieistotnych szczegółach i przyczynkarstwie. Każdy przytaczany fakt i okoliczność służy uzasadnieniu stawianych tez i realizacji zamierzeń badawczych. Na bardzo wysoką ocenę dzieła nie mogą mieć wpływu pewne uwagi polemiczne, które wynikają jedynie z innej perspektywy badawczej, a przede wszystkim z troski, by to co bardzo dobre, było jeszcze lepsze.

Po pierwsze, wydaje się, że Autor skupił się jedynie na omówieniu teoretycznych zagadnień dotyczących cywilistów, dlatego nie zamieścił analizy wykorzystania prawa rzymskiego w praktyce ich sądów. Podsuwam wobec tego propozycję dla dalszych badań w tym zakresie. Po drugie, zabrakło mi nieco szerszego odniesienia do ustrojotwórczego znaczenia prawa rzymskiego oraz jego roli w wielkich sporach politycznych targających Anglią od czasów co najmniej Elżbiety I. Dla przykładu dokonania wielkich prawników common law, z Edwardem Coke na czele, były w dużym stopniu reakcją na rozwój prawa statutowego i odejście np. w Court of Star Chamber od prawa powszechnego na rzecz prawa statutowego. Prawo rzymskie ponadto, co najmniej przez dwa stulecia, było przez opozycję parlamentarną traktowane jako instrument budowy królewskiego absolutyzmu (oczywiście przy całej nietrafności tego zarzutu) oraz przejaw reakcji katolickiej. Po trzecie, szkoda, że Autor nie wyjaśnił, choć jest to dla niego wiedza zapewne oczywista, dlaczego procedura kanoniczna była procedurą romanistyczną. Po czwarte, i jest to zarzut terminologiczny, warto zastanowić się nad polskim przekładem terminu established church, którego istotę w mojej opinii lepiej oddaje „kościół państwowy” niż „kościół ustanowiony".

Niezależnie od tych kilku uwag uważam analizowaną tu monografię za dzieło o trudnej do przecenienia wartości poznawczej, do którego sięgnąć powinni nie tylko romaniści, ale i historycy prawa oraz wszyscy zainteresowani historią i prawem angielskim. Wskazuje to na jeszcze jeden, w moim mniemaniu bardzo istotny, aspekt dzieła Ł.J. Korporowicza. Otóż badania nad prawem rzymskim nie ograniczają się do przytoczonych w tytule przysłowiowych Digestów, dotyczą bowiem także szeroko pojętej obecności Romanitas w tradycji i dziedzictwie cywilizacji Zachodu. Czy tego chcemy czy nie, czy mamy tego świadomość czy wręcz przeciwnie, to Rzym jest wciąż kolebką naszej cywilizacji, a jego dziedzictwo przewija się przez wszystkie wieki i cząstki tego, co zachodnie i łacińskie. Recenzowana monografia jest kolejną, która to dobitnie pokazuje. 


\section{BIBLIOGRAFIA}

Berman H.J., Prawo i rewolucja. Ksztaltowanie się zachodniej tradycji prawnej, Warszawa 1995.

Blackstone W., Commentaries on the Laws of England, vol. 1, Philadelphia 1893.

Dębiński A., Misztal-Konecka J., Wójcik M., Prawo rzymskie publiczne, Warszawa 2017.

Helmholz R.H., Canon Law and English Common Law, London 1983.

Helmholz R.H., Roman Canon Law in Reformation England, Cambridge - New York 1990.

Hoeflich M.H., Roman and Civil Law and the Development of Anglo-American Jurisprudence in the Nineteenth Century, Athens 1997.

Ibbetson D., Common Law and Ius Commune, London 2001.

Jurewicz A., Sajkowski R., Sitek B., Szczerbowski J., Świętoń A., Rzymskie prawo publiczne. Wybrane zagadnienia, Olsztyn 2011.

Kennedy D., The Structure of Blackstone's Commentaries, "Buffalo Law Review" 1979, vol. 2(28).

Korporowicz Ł.J., Prawo rzymskie w Anglii w XVIII wieku. Nauczanie, studia, nauka, Łódź 2019.

Korporowicz Ł.J., Prawo rzymskie w orzecznictwie Izby Lordów w latach 1876-2009, Łódź 2016.

Krajewski P., Sitek B., Rzymskie prawo publiczne, Olsztyn 2006.

Levack B.P., The Civil Lawyers in England, 1603-1641: A Political Study, Oxford 1973.

Marzec Ł., Kilka uwag o sądownictwie Admiralicji w Anglii, „Zeszyty Prawnicze UKSW” 2004, vol. 1(1).

Marzec Ł., Civil lawyers w Anglii Tudorów i wczesnych Stuartów, „Czasopismo Prawno-Historyczne” 2003, vol. 55(2).

Marzec Ł., Prawo rzymskie w dawnej Anglii w świetle pogladów Artura Ducka, ,Zeszyty Prawnicze UKSW" 2006, vol. 6(2), DOI: https://doi.org/10.21697/zp.2006.6.2.08.

McIlwain Ch.H., Constitutionalism: Ancient and Modern, Ithaca 1947.

Minot M., The Irrelevance of Blackstone: Rethinking the Eighteenth-Century Importance of the Commentaries, "Virginia Law Review" 2018, vol. 104(7).

Pollock F., Maitland F.W., The History of English Law before the Time of Edward I, Cambridge 1898.

Richardson H.G., Azo, Drogheda, and Bracton, "The English Historical Review" 1944, vol. 59(233), DOI: https://doi.org/10.1093/ehr/LIX.CCXXXIII.22.

Richardson H.G., Tancred, Raymond, and Bracton, "The English Historical Review" 1944, vol. 59(235), DOI: https://doi.org/10.1093/ehr/LIX.CCXXXV.376.

Rocznik Stużby Zagranicznej Rzeczypospolitej Polskiej wedtug stanu na 1 kwietnia 1938, Warszawa 1938.

Stein P., Roman Law in European History, New York 1999.

Stein P., The Character and Influence of the Roman Civil Law: Historical Essays, London 1988.

Tarwacka A., Zabłocki J., Publiczne prawo rzymskie, Warszawa 2011.

Trevelyan G.M., Historia Anglii, Warszawa 1967.

Turner R.V., Roman Law in England before the Time of Bracton, "Journal of British Studies" 1975, vol. 15(1), DOI: https://doi.org/10.1086/385676.

Vinogradoff P., The Roman Elements in Bracton's Treatise, "The Yale Law Journal" 1923, vol. 32(8), DOI: https://doi.org/10.2307/788323.

Watson A., The Structure of Blackstone's Commentaries, "Yale Law Journal" 1988, vol. 97(5), DOI: https://doi.org/10.2307/796514. 
Pobrane z czasopisma Studia Iuridica Lublinensia http://studiaiuridica.umes.pl Data: 26/04/2023 16:24:06

Prawo rzymskie to nie tylko Digesta. Kilka uwag nad książką...

\begin{abstract}
Polish research on Roman law is traditionally concerned first of all on the private law and its reception in European legal systems. However, very few publications deal with the role Roman law played on the British Isles. One of the important exceptions is Łukasz Jan Korporowicz's research from the University of Lodz. This article analyzes his last book entitled Prawo rzymskie $w$ Anglii $w$ XVIII wieku. Nauczanie, studia, nauka. It describes the system of teaching Roman law in England in the $18^{\text {th }}$ century and the role that graduates of Roman studies at Oxbridge played in English society at the time. First of all, the pioneering nature of reviewed work was indicated, as a similar one has not yet been published not only in Poland, but also in the world. By analyzing the subsequent parts of the book, their critical analysis was made and its strong and weaker elements were indicated. The conclusions indicate a very high scientific level of the reviewed book.
\end{abstract}

Keywords: Roman law; system of teaching; Roman studies; English society 